\title{
M. Huseynova
}

Doctor of Philology, Professor

Azerbaijan State Pedagogical University, Azerbaijan, Baku

e-mail:huseynova.mahira@yandex.ru

\section{LEXICAL-STYLISTIC EXPRESSION AND EMOTIONALITY OF AZERBAIJANI FOLKLORE TEXTS}

\begin{abstract}
The aim of our study is to determine the differences between the expressiveness and emotionality of lexical expressions on the material of texts of Azerbaijani folklore.

Stylistic vocabulary is the core of the dictionary and is considered a key part of stylistics. Unlike other areas of the language, the dictionary is more advanced and finely fragmented due to the expressive qualities of words and meanings. The creation of this wealth and the study of the possibilities of expressing lexical units is the task facing the lexical style. A stylized dictionary explores the relationship between the true and figurative meanings of vocabulary style functions. Literary criticism and linguistic stylistics investigate the different meanings of a word in context, especially the emotional and expressive linguistic potential of various vocabulary components. In addition to descriptive synchronous lexicology, historical lexicology is also reflected in the style, that is, many authors insist that their etymological roots lead to a more vivid expression when restoring obsolete word meanings. Even the pronunciation of words and phrases is of great importance in the field of vocabulary research. The category of emotions is an emotional expression. The expression in folklore texts comes from various means and acts in various functions. The article discusses the features of synonyms that create expressiveness in a broader sense.
\end{abstract}

Key words: expression, lexics, synonym, word.

$$
\begin{gathered}
\text { М. Гусейнова } \\
\text { филология ғылымдарының докторы, профессор, } \\
\text { Азербайжан мемлекеттік педагогикалық, университеті, Азербайжан, Баку қ., } \\
\text { e-mail:huseynova.mahira@уаndex.ru } \\
\text { Аексика-стимистикалық тұжырым және азербайжан фолклоры } \\
\text { мәтіндерінің эмоционалдымығы }
\end{gathered}
$$

\begin{abstract}
Аңдатпа. Біздің зерттеуіміздің мақсаты - әзірбайжан фольклоры мәтіндерінің материалындағы мексикалық өрнектердің экспрессивтілігі мен эмоционалдылығы арасындағы айырмашылықтарды анықтау. Стилистикалық мексика сөздіктің өзегі болып табылады және стилистиканың негізгі бөлігі болып саналады. Тілдің басқа салаларынан айырмашылығы, сөздік сөздер мен мағыналардың экспрессивті қасиеттеріне байланысты жетілдірілген және ұсақталған. Бұл байлықты құру және лексикалық бірліктерді білдіру мүмкіндіктерін зерттеу лексикалық стильдің а^дында тұрған міндет. Стильдендірілген сөздік сөздік стиль функцияларының шынайы және бейнелі мағыналарының арасындағы байланысты зерттейді. ӘАеби сын және мингвистикалық стилистика контекстегі сөздің әртүрлі мағыналарын, әсіресе эмоциона^ды және экспрессивті ^ингвистикалық потенциалдың әр түрлі компоненттерін зерттейАі. Сипаттамалық синхронды лексикологиядан басқа, тарихи лексикология стильде де көрініс табады, яғни көптеген авторлар ескірген сөз мағыналарын қалпына келтіргенде олардың этимологиялық тамырлары анағұрлым айқын көріністерге алып келеді деп сенеАі. Тіпті сөз бен сөз тіркестерінің айтылуы мексиканы зерттеу саласында үлкен мәнге ие. Эмоциялар категориясы - эмоционалды көрініс. Фольклорлық мәтіндегі өрнек әр түрлі құралдардан келеді және әр түрлі қызмет атқарады. Мақалада кең мағынада экспрессивтілік тудыратын синонимдердің ерекшеліктері қарастырылады.
\end{abstract}

Түйін сөздер: өрнек, мексика, синоним, сөз. 


\author{
М. Гусейнова \\ Аоктор филологических наук, профессор, \\ Азербайджанский Государственный Педагогический Университет, \\ Азербайджан, г. Баку, e-mail: huseynova.mahira@yandex.ru
}

Аексико-стимистическое выражение и эмоциональность азербайджанских фрольклорных текстов

\begin{abstract}
Аннотация. Целью исследования является определение различий между выразительностью и эмоциональностью ^ексических выражений на материале текстов азербайджанского фольклора. Стилистическая лексика является ядром словаря и считается к^ючевой частью стилистики. В отличие от Аругих областей языка, словарь более продвинутый и точно фрагментированный изза выразительных качеств слов и значений. Создание этого богатства и изучение возможностей выражения лексических единиц - задача, стоящая перед лексическим стилем. Стилизованный словарь исследует связь между истинным и переносным значениями функций словарного стиля. Аитературная критика и лингвистическая стилистика исследуют различные значения слова в контексте, особенно эмоциональный и выразительный языковой потенциал различных компонентов словарного запаса. Помимо описательной синхронной лексикологии, историческая лексикология также отражается в стиле, то есть многие авторы настаивают на том, что их этимологические корни приводят к более яркому выражению при восстановлении устаревших значений слов. Ааже произношение слов и фраз имеет большое значение в области исследования словарного запаса. Категория эмоций - это эмоциональное выражение. Выражение в фольклорных текстах происходит из различных среАств и действует в различных функциях. В статье рассматриваются особенности синонимов, которые создают выразительность в более широком смысле.
\end{abstract}

Ключевые слова: выражение, лексика, синоним, слово.

\section{Introduction}

Impression, richness, impact, expressiveness, simplicity, clarity, harmony, emotion, are the basis of both verbal and written speech acts, and the observance of these norms of speech facilitates serves its soundness, logic and accuracy. The word problem is an area that needs extensive and in-depth research in modern linguistics, and its expressive paints, among other features of the word, has been the focus of linguistic science in recent years.

The aim of our study is to determine the differences between the expressiveness and emotionality of lexical expressions on the material of texts of Azerbaijani folklore. First of all, the issue of expressive vocabulary is the subject of research in lexical styles. "Lexical styles constitute the core of style which is considered the main part of it. Because, unlike other areas of the language, vocabulary is a more advanced and more precise field of expression because of the expressive qualities of words and meanings; vocabulary is synonymous with richness "(Vinogradov, 1955:67). Creating this richness and exploring the possibilities of lexical units' expressiveness is a major challenge facing lexical styles (Ofəndiyeva, 1980:4). It should be noted that some of the studies on Azerbaijani stylistics have confused each other with expressive features of language and emotion, and the boundaries between them or their similarities and differences have been ignored. Whereas, there is a striking difference between expressiveness and emotionality.

\section{Main body}

The word "expressivity" is derived from Latin, meaning "comprehension, impact, expressiveness" (Altayl1, 1994:355). The word "emotionality" is derived from the French language, meaning "to create excitement and feeling" $(3,376)$. Thus, the expression of expression, whether oral or written, should be used to stimulate emotion, that is, to excite the reader or listener. A.Demirchizade also correctly points out that words, in addition to the basic logical and grammatical meanings, have different meanings and even some other senses in relation to a particular aspect of communication; that is, every word has a basic meaning in communication, additional meaning and also expressiveness and emotion (Dəmirçizado, 1962:73). A. Demirchizade also points out that some stylistic linguists have only understood or expressed the word's expressiveness, emotion, and some have different interpretations of expressions of color and expressive expressions of the word. But this is not what it is; that is, the color of the word, as we have seen above, consists of a number of important elements, and emotionality is one of those elements. (4, 75) Apart from the denotative meaning of words in words, whether in Azerbaijan or in non-relatives or relative languages, it also has a connotative meaning of emotional, expressive, and functional-style 
components. Consider the following examples: girl, maiden, lass, lassie, chick, baby, young, lady, and other words are used in English to mean "girl". However, their scope depends more on the characteristics of a girl than on the attitude and social status of the word artist. Synonyms, which are neutral in terms of the word "chiry" are in the dominant position.

The word "lassie" has the same subtle emotional tone and refers to the southern dialect of the English language. The Azerbaijani linguist A. Humbatova notes that the words "chick" and "baby" are more commonly used in spoken language than in simple terms: "young lady" refers to the elegant English style and the noble language. Connotative meaning is not only in lexical units, but also in morphological forms and syntactic structures. Connotations can be both simple and casual, meaning that a word or word combination with the expected style may act in a completely different context. In our view, the main task of the lexicon research is to find out the main styles of exclusion of words when it comes to speech, where emotion and expression play an important role. Emotionality and expression are learned as a result of the comparison of relatives and nonrelated languages. Azerbaijani and English literary criticism and linguistic stylistics explore different meanings that arise in the context of the word, especially the emotional and expressive language potential of different vocabulary, dialect words, terms, spoken sounds, neologisms, archeisms, tropes, etc., belongs to be used in both the English and Azerbajan languages. The category of emotion expresses emotion. Words of this nature are speech units that express these feelings. Emotional meaning can exist in words both independently and in substance. For example, there is almost no similarity between the words "honey" and "duck However, figuratively, the words "honey" and "duck" are synonymous. Some emotional expressions, in particular the expressions of emotion, are expressed in general, regardless of whether they are generally used in negative and positive ways:

Oh, Selim! Fell me yet in time

Nor leave thus to thoughts of fear.

$\mathrm{Ah}$ ! Yonder see the chocodar,

My father leaves the mimic war

(Ç.Ç.Bayron, The Bride of Abydos).

When Isabala woke up to Dunya khanim's voice, she saw her crying, let's see what the lady said in reply:

Don't cry, don't cry, hey Dunya khanim,

The son may die, but not to go from here!

\author{
May you be sacrificed for my sweet soul \\ The son may die, but not to go from here! \\ Ağlama, ağlama, ay Dünya xanım, \\ Ölər əcəm oğlu, getməz bu yerdən! \\ Sənə qurban olsun bu şirin canım, \\ Ölər əcəm oğlu, getməz bu yerdən!
}

İmprovisation: - "Yes, a son of Persia from Constinople to sentari to see thee. He well die, but well not lenve thut place. Five hundred crows can do no an eagle. The son of Persia well die, but well not leave that place". The uncertainty of emotional words is of great importance for stylistics. Thus, during the lexical analysis of styles, additional interpretations are needed regarding the emotions that the characters feeling.

Oh! Who young Leil's glance could read

And keep that portion of his creed

Emotional lexics should be distinguished by emotional expressions: fear, delight, gloom, cheerfulness, annoy, denonut connected assosiations with, emotional dependence on reactions and so on. from a linguistic point of view, these belong to separate groups

Expression is formed in both oral and written speech. Expression is, above all, an instrument of influence, and serves to actualize one or the other meaning and power of influence. It is very important that an event is presented in an express way. This situation sometimes occurs in the dialectal range, then either expands, generalizes, or remains within a limited circle. In particular, synonymy, omonymy, dialect and verbal variations, euphemisms, argo and taboo words, and other language tools, including phrases, idiomatic expressions, play an important role in the formation of expression. In the Azerbaijani language, lexical-style layouts, which are distinguished from each other for formal expressions, can also be used in vocabulary, which can be distinguished from each other by vocabulary and semantic and expressive vocabulary. It is very easy to define the perfect and detailed research criteria in terms of style. Undoubtedly, first among the categories that create style and expressiveness are synonyms. Therefore, as synonyms that make up a large part of the Azerbaijani language's vocabulary, as a factor that facilitates the expressiveness and impact of speech acts, we consider it appropriate to speak a little more in this language category as a styleexpressing creator: Almost all of the Russian, European and Azerbaijani stylists consider the use of synonymy, that is, the choice of language means and the rules of use of speech acts as the most important 
research object. Russian stylist A.I. Yefimov writes that synonyms of speech are the central problem of stylistics. (Yefimov, 1961^253)

The main characteristic of expressive synonymy which is a normative character is the development of speech culture. That is, the style means expressive synonymy and the logical and practical selection and use of relevant language tools. Different sounds that have the same meaning in the language are synonymous with grammatical and lexical phrases, and the more the language becomes rich with synonymic units, the more powerful the expressive and affective power. In other words, lexical units, which are divided into ideological and stylized synonyms, can become the most powerful means of impacting speech acts, and attention should be given to the study and study of these areas in style-expression. Note that lexical units that form a synonym for language express a common understanding both in neutral and expressive form. The additional expressive shades of these lexical units also vary in quality. For example, when we look at the effect of the word "have been died", that is, its expressiveness, we can see that there are shades of regret and sadness. "He went to that world" in written and spoken acts; "Died"; "Went to mercy"; "Dedicated his life to young people"; "Closed his eyes forever"; "Became a gorbagor" and so on. synonymic arrays express a common conception in both neutral and emotionally expressive ways: It turned out that both Murov and his squadron were sent to that world (the epic "Kachak Safarali"); Not hidden from God, what I hid from the people, my parents died(the epic "Kachak Safarali"); Now this is what our mother has done, her mother went to mercy (the epic "Kachak Safarali"); That's what brought us here now, her mother went to mercy (the epic "Kachak Safarali"); It has been a day since the elderly have donated their lives to young people (the epic of Ashug Ali and Süsenber); It was an accident, the wheel got used to it, my dear ones died (the epic of Ashug Ali and Süsenbar) and so on.

As can be seen from the examples, a similar concept has been manifested by neutral units as well as with euphemistic and dysfemic units added to that neutral unit. By the word "to die" it is possible to identify the synonym row and the expression created by that line: to die $\rightarrow$ to send to that world $\rightarrow$ to move out of the world $\rightarrow$ to die $\rightarrow$ to donate to life $\rightarrow$ to go to $\rightarrow$ to die $\rightarrow$ to become gorbagor. Azerbaijani is very rich with such lexical units. This is one of the factors proving the power, flexibility, expressiveness and impact of our language. Such synonymic units "... have a polysemantic sense, even if they are as close as they are to each other, even if they are similar to each other" (Cəfərov, 1958:44). "So synonyms are common terms, but they refer to different aspects of the same concept, to define one or the other aspect" (Ofəndiyeva, 1980:31) "connects it with different concepts and thus clarifies its distinctive features" (Reformatsky, 1953:62). The synonymy listings used to emphasize the superiority of each item and event in the language of any artistic work will sweeten the language of the work, make it attractive, and give the reader an emotional feeling. Synonyms of this style are used to extend the range of images and poeticized images in poetry, to increase their influence and enhance their expressiveness.

To determine the expressions of any synonymic unit, it is necessary to analyze it from a linguistic point of view. For example, spring-fountain synonyms express a common understanding and enhance their expressiveness when used in any literary text: Flowing like Abi-Kovsar, Cheshman, the king mountain of the spring (Ashug Alasgar); As Leyli promised to the spring, Majnun's only one, I sacrifice to you (Ashug Alasgar). In the first poetic text, the word artist created both panoramic and acoustic expressions of acoustic patterns. Or, if we look at the expressive sounds of -fire-pomegranate synonym, we can see that these lexical synonyms are not words that can be used interchangeably. "On the contrary, every synonym word in the synonym row has the meaning of expression and the color of the speech has a highlighting point in the speech. None of the synonymous purposes is used instead of the synonym (Ofondiyeva, 1980:31-32). Note the following examples from Ashug Alasgar: Love does not burn with fire, Puhan-pahan is dressed like me; The word is bad to me from the fire of doomsday; Don't burn too much, Alesker, don't shy from your health, Alesker. Eşq oduna yanan aşkara yanmaz, Pünhan-pünhan mənim kimi saralı; Qiyamət odundan pisdi mənə söz; Ataş olub çox da yanma, Oləsgər, Səhətindən heç usanma, Oləsgər; bir saat camalın görməsəm ölləm, Görsəm də yanıram nara, Bəynişan; Bivəfa gözəlin mənə sözləri, yandırdı odlarda, közlərdə məni.

Expressive paints and shades are also presented in the above examples, since the words "nar" in the language of the classical writers and poets are intensively used in our modern language. M. Huseynov also rightly points out that the word adapts to its surroundings to maximize lyrical thinking. In the form of poetic quality, the surrounding style plays a role of power and acts as a fact of art. Sweet - some rhythm and 
intonation shades define the vocabulary of the artistic environment directly related to the rhyme system. Thanks to a sense of poetic dimension and sensitivity to language, synonyms become a means of communication between the author and the listener. By its agility, synonyms acquire artistic prestige, and the aesthetic effect is reinforced by the essential stylistic-semantic flexibility of the word components that make up the art of speech. (Hüseynov, 2017:201) Synonyms for speech are the most useful language units that prevent duplication in both written and oral speech, directing it to an effective, expressive, aesthetic enjoyment. One of the ancient rhetoricians, Anaksimen notes that whatever the view is, it must be shaped differently. To do this, you need to change the phrases so that the same thoughts are not repeated in the same words. Then our speech will have a positive effect. (Antique theories of language and style, 1936:171)

In the Azerbaijani language, most synonyms are expressive. If any object, event, or feature described in any folklore pattern is alike, even if it is a little different to each other, then there is a need to use synonyms, which, of course, means the emergence of expression. For example, in our language, along with the verb "to go", it means "to walk", "to departure", "to get in the way", "to get off the road", "to turn away", synonyms such as "to move", "to jump", "to hit", "to get heel" and "to reject" are also used. For example: The fugitives went up the hill (The epic "Kachak Safarali" ); The girl walked home (the epic of "Ashug Ali"); They made their way to the Mount of Agri (the epic of Ashug Ali); They departed from the cohort and made their way to the village of Jani (the epic of "Kachak Safarali" ); Kerem set out to Erzurum with Lele on a frosty day (the epic of "Esli and Kerem"); He stepped out of the tent and turned towards the desert (the epic of "Esli and Kerem"); He was heading towards the village (the epic of "Ashug Ali"); Horses were going heavily (the epic of "Kachak Safarali"); When I came to Erzurum, I saw a great snowfall (the epic of "Esli and Kerem"); He would first hit the cohort where the fugitives were living (the epic of "Kachak Safarali" ); They gradually took the heel (the epic of "Kachak Safarali" epic); The girl said: "Get out of my door, humiliating, dishonest!(the epic of "Kachak Safarali") and so on.

The repeatings of meaning in the speech, the excessive using of lexical synonyms are of particular importance.The majority of synonymic lines provide a complement to the general semantics of the text, and play a role in stimulating poetic expansion and expressive action. The overall force of the lexical synonyms listed further enhances the image. In other words, lexical synonyms are one of the strongest semantic-style categories to express the most subtle meanings of thought, to achieve maximum expression, and to create style fluidity. Synonyms, a phenomenon associated with polysemy, are enlarged and enriched at the expense of polysemy. The semantics of the multidimensional word, or figurative meaning, may be included in this or other synonymic sequence and may be an equal member of the word, thus further emphasizing the metaphorical meaning of euphemisms, by the use of multidimensional words, Synonyms, composed of emotionally expressive words, archaic, and articulated by different words, play a very important role in the expression.

\section{Results}

From this point of view, based on the fiction materials we collect from folklore texts, we can briefly review them as follows:

1.Expression of synonyms formed by multiplicity. Because polysemy is the body and blood of synonyms, the emergence of expression depends primarily on the plurality of words. Because multidimensionality is enriched and expanded at the expense of synonymic lines. "One of the secondary or metaphorical meanings of the multidimensional word is that by virtue of its semantics it may enter into one or another synonymic sequence." $(2,34)$ For example, if we look at the semantic meanings of the word "to lose one's head" often used in folklore texts, we can base our thinking: The fugitives lost themselves and lost their head ("the epic of Kachak Safarali" ); He was often mistreated (he epic of Kachak Safarali); The son said: - Daddy, I am so tired and lost myself (the epic of Kachak Safarali); The brooding horse was stunned (the epic of "Kachak Safarali"); Pristav lost his head (the epic of "Kachak Safarali") and so on. Qaçaqlar özlərini itirdilər, çaşdılar ("Qaçaq Səfəralı" dastanı); O tez-tez yamanca yanılırdı ("Qaçaq Səfəralı" dastanı); Oğul dedi: - Ata, mən lap karıxmışam, özümü itirmişəm ("Qaçaq Səfəralı" dastanı); Kürən at qarıxmışdı ("Qaçaq Səfəralı" dastanı); Pristav başını itirmişdi ("Qaçaq Səfəralı" dastanı) və s.thus, the dominant word in these examples is "to lose one's head" and as a result, the possibilities of synonymic imagery, expressiveness are increased and enriched so that these templates themselves are distinguished by their colour and style, and the number of examples in folklore is up.

2.Expression of synonyms formed by the words taken from another language. Acquisition words 
also play an important role in the enrichment of synonymic lines and even such derived words used in folklore texts have equivalent in our language. For example, in folklore texts, the equivalent of the word "face(üz)" (sima, sifət, surət, camal, çöhrə, rüxsar, bəniz) used intensively which are native to our mother tongue: He did not look at his face (the epic of "Kachak Safarali"); Your face is nice from a holiday month (Ashug Alasger); Troublesome thoughts covered his face (from the spoken language); His face was saddened (the epic of "Kachak Safarali") İn Asmar's pale face was seen a cold kindness(the epic of "Ashig Ali" ) and so on.

O, üzünə baxmadı ("Qaçaq Səfəralı” dastanı) ; Camalın göyçəkdir bayram ayından ( Aşıq Đləsgər); Kədərli xəyallar və fikirlər onun simasını örtmüșdü ( danışıq dilindən); Onun sifətini kədər çulğalamışdı ("Qaçaq Səfəralı" dastan1) Osmərin solğun bənizində soyuq bir mehribanlıq görünürdü (“Aşıq Alı" dastanı) və s.

3.Expression of synonyms related to euphemism: Synonyms related to euphemisms are also one of the most important tools in helping to get folklore texts more meaningful, expressive and complete. For example, it is known that the word "born" is weak in terms of expression. And also it does not sound good in terms of ethics. But when you replace this word with euphemistic synonyms, the expressiveness of the expression is increased, and at the same time the rules of courtesy are followed. We can base our thoughts on an example from the epic of Ashug Ali and Susenber: Days passed, weeks passed. It was nine months, nine days, nine hours, nine minutes, nine seconds. Shikh's son's wife put her luggage on the ground. Apparently, the preference for the euphemistic expression of "put her luggage on the ground " in order to soften the thought of the dominant word of to bear, in this way, more expressive and cultural. Note that synonymic sequences are also used intensively to create expressions (doğdu- anadan oldu - dünyaya gəldi - təvəllüd etdi)in folklore texts.

4. Expression through figurative synonyms: Expression through metaphorical synonyms refers to the role of phraseology in the enrichment of synonymic lines in folklore texts, because each phraseological unit in the language of the samples we analyze is equivalent to a particular word. For example, used in folklore texts, "keep your eyes on the road," "stare your eyes on the road," "ruin the palace of life," "plunge into trouble"; return to the mountain, "walk to the feet", "climb the smoke hill", "to go black all day", "to paint life with blood" and so on. Hundreds of synonym phrases such as these are found in folklore texts: Let the bride rejoice in the sight of the bride, the daughters, and the wires of Daras's hair. ("Daralayez folklore"); My eyes were on the road, the ruins of the Palace of Life ("Daralayez folklore"); It never opens, eyebrows, foreheads, Shindirir sometimes teşti, sometimes the plate ("Daralayez folklore"). (Gözü yolda qalan gəlinlər, qızlar, Darasın saçını tellər sevinsin. ("Dərələyəz folkloru"); Gözümü yollara dikdi, Ömrün sarayını sökdü ("Dərələyəz folkloru”);Çox bəlalar çəkdi başım, İtkin düşdü qonum-qonşu ("Dərələyəz folkloru"); Açılmır heç zaman qaşı, qabağı, Sındırır gah teşti, gah da tabağı ( "Dərələyəz folkloru") və s.)

5. Expression of synonyms of emotional and expressive words: Synonyms of emotional and expressive words also play a very active role in the expression. In folklore texts, both positive and meaningful (humor, lamb, nightingale, charming, sacrificing, feathers, hugs, gazelles, deer, halal, goodwill, Allah, billah, etc.), or negative meaning (humiliation, lashar). , the son of a lame, a dog, a nasty, a hell, a dog from my head, one of them, stuck in the ground, blind, etc.) The words are innumerable, and they are powerful in expressing expression and feeling of excitement speech units. For example: Afarin, the Turkish son said Pasha, Let Koch live, my son, live one hundred years old ("Daralayez folklore"); You are the master of the craftsman. ("Daralayaz folklore"); Welcome to the word! ("Daralayaz folklore") and so on. (Məsələn: Afərin, türk oğlu söylədi Paşa, Qoç ata var olsun, oğul yüz yaşa ("Dərələyəz folkloru"); Var olsun hörən ustadın, Pərvanələr çırağısan. ("Dərələyəz folkloru"); Saz götürüb qulluğunda durmuşam, Sənətdə vurğunam sözə xoş gəldin! ("Dərələyəz folkloru") və s.)

6.Expression of archaic synonyms: The enrichment of synonyms also comes at the expense of archeisms, which also give rise to excitement as they read and thus express themselves in various events of real existence. For example, the dubbing synonym for "brave, brave, hero," in our modern language, also uses archaic word "husband" to express expressions in these moments: My life as a husband, the fire of this mortal world! ("Dereleyez folklore"); Not to mention, A husband made his son a husband ("Dereleyez folklore") and so on. (Oliyəm ər kimi yaşayıb keçdim, Bu fani dünyanın odundan, oğul! ("Dərələyəz folkloru"); Mərifətdə söyülməyən, Or oğlunu or yaradıb("Dərələyəz folkloru") və s. 


\section{Conclusion}

Expressionism is a broader category than emotion, and Y.M.Kalkina-Fedoruk's views on this are justified. The stylistics shows that expression is not only in the speech of the person, but in movement, facial expressions, general behavior, and even work. Expression or expression can be characterized by expressions of both emotional and intellectual and willpower. But English lexicographers refer to the same category of emotion and expressiveness. In their view, expression is always at the expense of emotionality.Thus, it is not enough for the folklore texts that we have considered in the form of abstracts. Because there are many tools involved in enhancing expression, which is also the subject of extensive research. Grammatical and morphological tools are also actively involved in folklore texts, which will be widely discussed in our future research.

\section{References}

Altaylı S.(1994) Azərbaycanca-türkcə sözlük. İstanbul.

Antique theories of language and style. (1936) OGIZ, M-L

Ofəndiyeva T. (1980) Azərbaycan dilinin leksik üslubiyyatı. Bak1, "Elm".

Dəmirçizadə Ә. (1962) Azərbaycan dilinin üslubiyyatı. Bak1, Azərtədrisnəşr.

Hüseynov M. (2017) Aşıq Oləsgərin söz ümmanı. Bak1, "Elm və təhsil".

Reformatsky A.A. (1953) Introduction to linguistics. M.

Cəfərov C. (1958) Azərbaycan dilinin leksikası. Bak1.

Vinogradov V.V. (1955) Results of the discussion of stylistics issues. B. R, No. 1.

Yefimov A.I. (1961) The style of art speech. M. 